\title{
IMPLEMENTASI METODE JOYFULL LEARNING PADA PEMBELAJARAN PENDIDIKAN AGAMA ISLAM DI SEKOLAH MENENGAH PERTAMA ALAM BANYUWANGI ISLAMIC SCHOOL
}

\author{
Elmania Alamsyah \\ elmaniaalamsyah@gmail.com \\ Program Studi PAI FTIK IAIN Jember \\ D. Fajar Ahwa \\ diambangfajar@gmail.com \\ Program Studi PAI FTIK IAIN Jember
}

\begin{abstract}
ABSTRAK
Pembelajaran Pendidikan Agama Islam atau sering disingkat dengan PAI kurang diminati oleh peserta didik. Hal ini terbukti dengan kurangnya respon semangat ketika pembelajaran PAI dimulai, pasif, kurangnya rasa responsif pada pembelajaran. Hal ini disebabkan oleh kurangnya tenaga pengajar yang kompeten, mengajar dengan pemaksaan serta kurangnya waktu pada Pembelajaran. Untuk itu dengan menggunakan metode yang menyenangkan atau joyfull learning diperlukan dalam mengatasi permasalah tersebut. Data ini relasinya dengan judul "Implementasi Metode Joyfull Learning Pada Pembelajaran Pendidikan Agama Islam Di Sekolah Menengah Pertama Alam Banyuwangi Islamic School." Metode Penelitian ini menggunakan penelitian kualitatif, dengan menggunakan teknik pengambilan sampel purposive sampling. Jenis pendekatan menggunakan narative research (penelitian naratif). Metode pengumpulan data menggunakan observasi, wawancara dan studi dokumentasi. Analisis data model Miles Huberman yang meliputi: kondensasi data, penyajian data, verifikasi dan kesimpulan. Keabsahan data menggunakan triangualasi teknik dan sumber. Penelitian ini memperoleh kesimpulan (1) Implementasi metode joyfull learning pada pembelajaran PAI adalah dengan cara menerapkan outbound and moving class, outdoor class, mind mapping, pelatihan (training of trainer), game pelajaran disertai dengan iringan musik melalui pengeras suara loud speaker, disamping itu juga menerapkan hafalan dengan super memory rumus. (2) Faktor pendukung implementasi metode joyfull learning pada pembelajaran PAI di SMP Alam BIS adalah motivasi semangat dari peserta didik untuk belajar, sedangkan faktor penghambatnya adalah kurangnya kreativitas pendidik menerapkan permainan dalam mengajar menggunakan metode joyfull learning.
\end{abstract}

Kata Kunci: joyfull learning, pembelajaran pendidikan agama Islam, sekolah menengah pertama

\footnotetext{
ABSTRACT

Islamic Religious Education or often abbreviated as PAI is less desirable by students. This is evidenced by the lack of enthusiasm response when PAI learning begins, passive, lack of responsiveness to learning. This is due to the lack of competent teaching staff, coercive teaching and lack of time in learning. For this reason, using a
} 


\section{AL-ADABIYAH: Jurnal Pendidikan Agama Islam}

fun method or joyfull learning is needed to overcome these problems. This data is related to the title "Implementation of Joyfull Learning Methods in Learning Islamic Religious Education in Alam Banyuwangi Islamic Middle School." This research method uses qualitative research, using purposive sampling technique. This type of approach uses narrative research. Data collection methods use observation, interviews and documentation studies. Analysis of Miles Huberman model data which includes: data condensation, data presentation, verification and conclusions. Data validity uses triangualation techniques and sources. This study obtained conclusions (1) The implementation of the joyfull learning method in PAI learning is by implementing outbound and moving classes, outdoor classes, mind mapping, training (training of trainers), game lessons accompanied by musical accompaniment through loud speaker, besides it also applies rote memorization to the super memory formula. (2) The supporting factor of the implementation of the joyfull learning method in PAI learning at SMP Alam BIS namely is leass motivation of the students to learn, while the inhibiting factor is the lack of creativity of the educator applying the game in teaching using the joyfull learning method.

Keywords: Islamic religious learning, joyfull learning, junior high school

\section{Pendahuluan}

Pembelajaran di sekolah harusnya mampu menjadikan peserta didik untuk memahami, menikmati proses belajar dan mengimplementasikan hasil belajarnya dalam kehidupan sehari-hari. Namun sangat disayangkan, harapan tak sesuai dengan ekspetasi yang direncanakan dalam pendidikan. Undang-Undang No 20 Tahun 2003 tentang Sistem Pendidikan Nasional dijelaskan bahwa:

Pendidikan adalah usaha sadar dan terencana untuk mewujudkan suasana belajar dan proses pembelajaran agar peserta didik secara aktif memiliki kekuatan spiritual keagamaan, pengendalian diri, kepribadian, kecerdasan akhlak mulia, serta keterampilan yang diperlukan dirinya, masyarakat, bangsa dan negara. ${ }^{1}$

Undang-undang tersebut menjelaskan keinginan adanya suatu pendidikan yang paling utama ialah agar peserta didik secara aktif memiliki kekuatan spiritual keagamaan. Selain itu dalam Undang-undang tentang Sisdiknas tertulis, pada pasal 40 ayat (2) berbunyi "pendidik dan tenaga kependidikan berkewajiban menciptakan suasana yang bermakna, menyenangkan, kreatif, dinamis dan dialogis". Keadaan tersebut harus dibangun oleh pendidik tanpa membedakan genre ilmu, baik secara umum maupun ilmu agama. Masalah terbesar dalam pembelajaran ini, yakni munculnya anggapan-anggapan yang kurang menyenangkan tentang Pendidikan Agama Islam yang mana materi yang sering

\footnotetext{
${ }^{1}$ Sekretariat Negara RI, Undang-undang No 20 Tahun 2003 tentang Sistem Pendidikan Nasional
} 


\section{AL-ADABIYAH: Jurnal Pendidikan Agama Islam}

disuguhkan selalu melalui hafalan, pembelajarannya yang monoton, kaku sehingga kurang diminati oleh peserta didik.

Hal ini terbukti statment yang disampaikan oleh Muhadjir Effendy sebagai Menteri Pendidikan dan Kebudayaan Republik Indonesia tahun lalu bahwa "minimnya pendidikan agama di sekolah umum disebabkan oleh kurangnya tenaga pengajar yang kompeten, melaksanakan proses pembelajaran dengan pemaksaan. Dalam acara seminar yang digelar oleh alumni Pendidikan Guru Agama (PGA)."2 Terkait dengan pernyataan tersebut, substansi dari pendidikan Islam penuh dengan esensi yang wajib dipraktikkan. Namun pada realitanya, tidak sedikit proses pembelajaran yang dilaksanakan cenderung membosankan di kelas. Padahal, ketika memasuki sebuah sekolah, sebenarnya peserta didik dan pendidik sedang memasuki sebuah lingkungan belajar. Namun kenyataannya, lebih sempit lagi, mereka memasuki sebuah gedung yang masih terbagi lagi menjadi beberapa ruangan yang sering disebut dengan kelas. ${ }^{3}$

Sementara untuk membantu melancarkan pembelajaran, dibutuhkan adanya panca indera, misalnya jika lingkungan belajar tidak memuaskan indra mata seperti gambar dan tulisan tidak menarik, tidak ada alunan ritme nada yang terdengar oleh telinga. Ditambah udara pengap dan tidak sejuk maka yang terjadi adalah terganggunya proses pembelajaran, sehingga peserta didik kurang berminat untuk belajar.

Akan tetapi, berbeda bila menerapkan pembelajaran yang menyenangkan atau joyfull learning. Joyfull learning merupakan suatu sistem proses pembelajaran secara menyenangkan. ${ }^{4}$ Joyfull learning menyajikan cara belajar yang asyik, dimana peserta didik diajak belajar sambil bermain, artinya proses pembelajaran dikemas dalam situasi menyenangkan, baik dilaksanakan di dalam kelas maupun di alam sekitar. Melalui pembelajaran yang menyenangkan diharapkan mampu menciptakan daya minat, kreativitas dari siswa secara sempurna, sehingga menumbuhkan proses pembelajaran yang baik.

Untuk itu, patutnya instansi pendidikan mampu menciptakan sistem pembelaj aran yang menyenangkan membuat dimana peserta didik tidak tertekan,

2 Nur Hayati, "Mendikbud Singgung MinimnyaPendidikan Agama di Sekolah," Serambinews, diakses 21 Oktober 2019, https:aceh.tribunnews.com/2018/05/06/mendikbud-singgungminimnya-pendidikan-agama-di-sekolah.

${ }^{3}$ Munif Chatib dan Irma Nurul Fatimah, Kelasnya Manusia: Memaksimalkan Fungsi Otak Belajar dengan Manajemen Display Kelas (Bandung: Kaifa, 2015), 21.

${ }^{4}$ Agus Nurjaman, Joyful Learning Mencuatkan Kreativitas Siswa (Bandung: Guepedia, t.t), 3. 


\section{AL-ADABIYAH: Jurnal Pendidikan Agama Islam}

bahagia, dan mampu menikmati pembelajaran yang sedang berlangsung. Salah satu instansi pendidikan yang menerapkan sistem pembelajaran menyenangkan yaitu di Sekolah Menengah Pertama Alam Banyuwangi Islamic School. Sekolah ini bertempat di Desa Jenesari Kecamatan Genteng Kulon Kabupaten Banyuwangi.

Berdasarkan hasil dari penelitian pendahuluan yang peneliti lakukan dengan kepala sekolah dan melalui artikel serta berita di televisi terkait dengan objek di Sekolah Menengah Pertama Alam Banyuwangi Islamic School atau sering disingkat dengan SMP Alam BIS. Yang mana SMP Alam BIS merupakan sekolah yang berhasil dalam menerapkan pembelajaran yang menyenangkan dan unik. Keberhasilannya dibuktikan dengan seringkali di undang di berbagai acara televisi untuk melakukan seminar dan motivasi serta banyak mendapat penghargaan. Proses pembelajarannya tidak hanya dilaksanakan di dalam ruangan, namun juga di outdor dengan menggunakan pembelajaran menggunakan cara belajar yang menyenangkan. Ditambah adanya aspek kebaharuan penelitian di antara penelitian-penelitian terdahulu.

Dari uraian diatas penting untuk diteliti sehingga peneliti mengangkat tema "Implementasi Metode Joyfull Learning Pada Pembelajaran Pendidikan Agama Islam di Sekolah Menengah Pertama Alam Banyuwangi Islamic School", dilakukan sebagai wujud revolusi dalam menerapkan metode tersebut pada pembelajaran PAI. Tujuan dari pada penelitian ini adalah sebagai berikut:

1. Untuk mendeskripsikan tentang implementasi metode joyfull learning pada pembelajaran PAI.

2. Untuk menjelaskan faktor pendukung dan penghambat implementasi metode joyfull learning pada pembelajaran PAI di SMP Alam BIS.

\section{Tinjauan Literatur}

\section{Metode Joyfull Learning}

Di zaman modern saat ini banyak pembelajaran yang menyenangkan dengan berbagai metode dan tekniknya. Namun tidak banyak dari pendidik memahami dan mengaplikasikannya ke dalam proses pembelajaran, akibatnya banyak dari peserta didik yang jenuh belajar di kelas. Dampak dari kejenuhan ini peserta didik tidak semangat belajar atau kurang berminat belajar, sehingga menghambat tujuan pembelajaran. Misalnya timbul rasa malas untuk belajar, ilmu yang disampaikan oleh pendidik tidak diserap baik oleh peserta didik, proses pembelajaran tidak 


\section{AL-ADABIYAH: Jurnal Pendidikan Agama Islam}

kondusif dan lain sebagainya. Solusi untuk mengatasi masalah tersebut ialah menggunakan pembelajaran yang menyenangkan (joyfull learning). Joyfull learning berasal bahasa Inggris, joyfull yang artinya menyenangkan sedangkan learning yang artinya pembelajaran. Joyfull learning merupakan pebelajaran yang dalam prosesnya tidak menerapkan tekanan baik dari segi psikologis maupun fisik, dalam pelaksanannya diciptakan suasana yang menyenangkan, kreatif, penuh dengan kegembiraan. Pembelajaran menyenangkan bukan berarti mengajak peserta didik untuk tertawa terbahak-bahak, bersenang-senang, bermain-main terus.

Akan tetapi, pembelajaran yang menyenangkan terdapat daya tarik yang kuat antara pendidik dan peserta didik dalam keadaan yang tidak ada paksaaan di dalamnya. Radno Harsanto menyebutkan bahwa "menyenangkan adalah menjadikan senang, membuat bersuka hati, membangkitkan rasa senang hati, memuaskan, menarik hati, merasa puas dan sebagainya. Proses pembelajaran akan terasa menyenangkan jika peserta didik yang aktif di dalamnya." 5

\section{Metode Pembelajaran}

Menurut Djamaluddin dan Abdullah di dalam bukunya Darmadi bahwa "metode berasal dari kata meta yang berarti melalui dan hodos jalan. Metode adalah suatu jalan yang perlu dilalui untuk menggapai tujuan."6 Metode merupakan cara yang sudah direncanakan dan disiapkan secara matang dalam mencapai keinginan yang diharapkan. Menurut Slameto dalam bukunya Nining Mariyaningsih dan Mistina Hidayati bahwa "metode mengajar merupakan cara yang dilalui dalam mengajar, artinya metode pembelajaran ialah cara yang diimplementasikan yang sebelumnya sudah direncakan dan disusun dengan maksimal."7

1. Tujuan Metode Pembelajaran

Adapun tujuan dari metode pembelajaran menurut Halid Hanafi sebagai berikut:

a. Untuk membantu peserta didik mengembangkan pengetahuan, keterampilan, sikap kepribadian yang baik.

\footnotetext{
5 Radno Harsanto, Pengelolaan Kelas yang Dinamis: Paradigma Baru Pembelajaran Menuju Kompetensi Siswa (Yogyakarta: Kanisius, 2017), 20.

6 Darmadi, Pengembangan Model Metode Pembelajaran dalam Diinamika Belajar Siswa (Yogyakarta: CV Budi Utama, 2017), 175.

7 Nining Mariyaningsih dan Mistina Hidayati, Bukan Kelas Biasa: Teori dan Praktik Berbagai Model dan Metode Pembelajaran (Surakarta: CV Kekata Group, 2018), 10.
} 
b. Untuk membiasakan berlajar memahami, berpikir sehat, rajin dan mengajukan ide atau pendapat.

c. Memudahkan proses pembelajaran sesuai dengan tujuan yang diinginkan.

d. Menghemat waktu, tenaga yang digunakan dalam menyampaikan materi

e. Menciptakan suasana belajar yang menumbuhkan semangat dan keaktifan di kelas. ${ }^{8}$

Berdasarkan pemaparan diatas dapat disimpulkan bahwa metode pembelajaran bertujuan untuk memberikan kemudahan bagi pendidik untuk menyampaikan materi dan peserta didik dalam memahami pembelajaran demi mencapai tujuan yang diinginkan.

2. Macam-macam Metode Pembelajaran

a. Metode Demonstrasi

Metode demonstrasi adalah salah satu metode pembelajaran dengan mempraktikkan suatu kejadian peristiwa untuk membantu peserta didik memahami materi pembelajaran atau memperoleh jawaban melalui pengamatan.

b. Metode Ceramah

Metode ceramah adalah suatu metode yang melibatkan pendidik untuk berperan aktif di dalam kelas. Sedangkan peserta didik hanya mendengarkan dan mencermati apa yang disampaikan oleh pendidik. Namun pada umumnya bila pendidik berlebihan dalam menyampaikan materi, maka peserta didik akan jenuh dan tidak memperhatikan materi pembelajaran. Untuk itu sebaiknya pendidik dapat mengatur porsi bicara dalam menyampaikan materi.

c. Metode Tanya Jawab

Dalam proses belajar dan mengajar dibutuhkan adanya pendidik dan peserta didik. Pembelajaran dikatakan berhasil ketika mampu menciptakan keadaan aktif di kelas. Menurut Bukhari Umar bahwa "metode tanya jawab dapat diartikan sebagai cara penyampaian yang dilakukan saat pelajaran dengan cara pendidikan mengajukan pertanyaan dan peserta didiknya yang menjawab."9

8 Halid Hanafi, La Adu, Muzakkir, Profesionalisme Guru Dalam Pengelolaan Kegiatan Pembelajaran Di Sekolah (Sleman: CV. Budi Utama, 2018), 123.

9 Bukhari Umar, Hadis Tarbawi: Pendidikan dalam Perspektif Hadis (Jakarta: Amzah, 2016), 127. 
d. Metode Diskusi

Diskusi merupakan kegiatan atau aktivitas beberapa kelompok peserta didik, dimana mereka saling tukar informasi ataupun pendapat tentang sebuah permasalahan atau topik. Dalam menerapkan metode diskusi, maka guru harus menyajikan suatu topik permasalahan untuk dibahas dan dipecahkan bersama antar kelompok.

e. Metode Kerja Kelompok

Menurut Darmadi mengungkapkan bahwa "metode kerja kelompok memiliki esensi dalam membentuk kedewasaan dan menambah potensi peserta didik dalam menguasai materi yang sedang dibahas secara bersama."10

\section{Pembelajaran Aktif, Inovatif, Kreatif, Efektif, Menyenangkan (PAIKEM)}

Pendidikan bukan hanya tanggung jawab dari pihak sekolah, akan tetapi juga semua pihak. Semua pihak yang dimaksud ialah lingkungan, sekolah dan keluarga, konsep ini diciptakan oleh Ki Hajar Dewantara yang dirujuk di dalam bukunya Kusni Ingsih dkk bahwa "yang disebut dengan tripusat pendidikan Tripusat Pendidikan diantaranya yaitu pendidikan di lembaga sekolah, pendidikan di masyarakat dan pendidikan di keluarga."11 Untuk itu dibutuhkan kerja sama antar ketiganya. Keluarga juga dapat membantu mendidik dan memotivasi anak untuk semangat dalam belajar. Sehingga memudahkan sekolah dalam melaksanakan pembelajaran, yang paling penting adalah sebenarnya peserta didik dapat menikmati proses pembelajarannya, merasa tidak terbebani, dapat aktif dan menyenangkan baik bagi siswanya guru maupun guru.

Disamping itu dalam membantu kendala kesulitan mengajar, pendidik dapat menerapkan PAIKEM. ${ }^{12}$ Penerapan PAIKEM ini dilatar belakangi oleh kondisi peserta didik yang malas dan bosan ketikan pembelajaran, yang mana pada umumnya siswa hanya duduk diam mendengarkan guru menyampaikan materi. Konsep dari PAIKEM bahwa pembelajaran harus berpusat pada siswa (student center learning) dan pembelajaran harus menciptakan kondisi yang menyenangkan.

\footnotetext{
10 Darmadi, 184.

11 Kusni Ingsih, dkk, Pendidikan Karakter: Alat Peraga Edukatif Media Interaktif (Yogyakarta: CV. Budi Utama, 2018), 44.

12 Ikhwan Sapto Darmono, "Peningkatan Kinerja Guru Dalam Pembelajaran PAIKEM

Melalui Supervisi Akademik Berkelanjutan Bagi Guru Kelas Di SD Negeri Pucangan 03

Kec. Kartasura tahun Pelajaran 2016/2017," Konvergensi 6, no. 29 (Juli, 2019): 30.
} 


\section{AL-ADABIYAH: Jurnal Pendidikan Agama Islam}

Menurut Rusman mengungkapkan bahwa "tujuan dari konsep ini adalah supaya termotivasi untuk belajar dengan kesadarannya, tanpa ada paksaan maupun merasa terbebani." 13

Aspek terpenting dalam konsep ini adalah supaya anak dapat termotivasi dalam belajar, sehingga dapat mengeksplorasi, kreasi, dan bereksperimen dalam pembelajaran. Tujuan PAIKEM adalah supaya terdapat adanya perubahan berpikir di bidang pendidikan, seperti yang dirancang oleh Depdiknas (Departemen pendidikan nasional) yaitu pendidikan di Indonesia harus berevolusi dari schooling menjadi learning, instructive menjadi facilitative, goverment role menjadi community role dan centralistic menjadi desentralistic. Artinya Pendidikan Indonesia harus berevolusi dari sekolah menjadi pembelajaran, intruksi menjadi fasilitator, peran pemerintah menjadi peran komunitas dan sentralistik menjadi desentralistik.

PAIKEM kependekan dari pembelajaran aktif, inovatif, kreatif, efektif dan menyenangkan. Berikut adalah penjelasannya:

1. Pembelajaran Aktif

Pembelajaran aktif menekankan siswa dalam keterlibatan aktivitas pembelajaran, bukan guru yang dominan menyampaikan materi pelajaran. Pembelajaran yang aktif di kelas lebih menekankan siswa dalam aktivitas belajar, mulai dari mencari informasi dan pengetahuan untuk dibahas dalam proses pembelajaran. ${ }^{14}$

2. Pembelajaran Inovatif

Pembelajaran inovatif lebih bersifat student centered.15 Yaitu pembelajaran yang lebih memberikan kesempatan bagi peserta didik secara mandiri untuk belajar dan dimediasi oleh teman sekelasnya. Pembelajaran inovatif berlandaskan pada pemikiran yang membangun, membentuk kembali atau mentransformasi informasi yang baru. Diharapkan dengan adanya pembelajaran secara inoatif dalam memajukan proses pembelajaran atau bertransformasi terhadap sesuatu yang baru.

3. Pembelajaran Kreatif

Untuk mewujudkan pembelajaran yang dapat memotivasi dan menarik perhatian siswa untuk belajar yakni dengan menerapkan pembelajaran yang

13 Rusman, Model-Model Pembelajaran: Mengembangkan Profesionalisme Guru (Bandung: PT Rajagrafindo Persada, 2016), 321.

${ }^{14}$ Husniyatus Salamah Zainiyati, Pengembangan Media Pembelajaran Berbasis ICT Konsep dan Aplikasi Pada Pembelajaran Pendidikan Agama Islam (Jakarta: Kencana, 2017), 8.

15 Darmadi, Pengembangan Model, 92. 
kreatif. Caranya dengan menerapkan variasi metode dan strategi yang tepat dengan materi dan kondisi peserta didik. Misalnya kerja kelompok, bermain peran dan pemecahan masalah. Dengan menerapkan pembelajaran yang kreatif dapat memicu kreatifitas peserta didik dalam mengembangkan potensi berpikir.

4. Pembelajaran Efektif

Memanfaatkan minat kemampuan dan kesiapan menerima pembelajaran akan mampu mencapai pembelajaran yang efektif. Pembelajaran yang efektif artinya pendidik dapat menghidangkan kompetensi-kompetensi efektif dalam pembelajaran.. Pembelajaran yang efektif tercipta atas dasar perencanaan, strategi dan metode yang baik serta pemilihan media yang tepat dalam pembelajaran. ${ }^{16}$

5. Pembelajaran Menyenangkan

Pembelajaran yang menyenangkan adalah proses penyampaian bahan ajar melalui metode pembelajaran yang menghadirkan suasana yang membuat hati peserta didik senang. ${ }^{17}$ Belajar tanpa ada tekanan dari siapapun, mereka dapat menikmati proses pembelajaran dengan hati yang gembira tidak kaku dan tidak tertekanan.

Dengan menggunakan PAIKEM (pembelajaran aktif, inovatif, kreatif, efektif dan menyenangkan) peserta didik muncul keinginan dalam belajar. Keinginan belajar muncul dari peserta didik ketika mereka tertarik dalam mengikuti proses pembelajaran. Ketertarikan pada suatu pembelajaran dipicu oleh ketepatan peserta didik dalam mengajar mulai dari metode nya, media, siatuasi kondisi belajar dan lain sebagainya.

\section{Pembelajaran Pendidikan Agama Islam}

1. Sistem Pembelajaran PAI

Proses adanya pembelajaran PAI ini sebagai wujud dakwah demi mewujudkan pemahaman dan kesadaran peserta didik dalam mencari ridha Allah SWT. Pembelajaran PAI harus dilaksanakan secara utuh dan kuat demi memperoleh tujuan secara optimal. Menurut Lorens Bagus yang dirujuk di dalam bukunya Rifki Amin bahwa "kata sistem berasal dari bahasa Inggris

16 Putri kumala Dewi dan Nia Budiana, Media Pembelajaran Bahasa : Aplikasi Teori Belajar dan Strategi Pengoptimalan Belajar (Malang: UB Press, 2018), 51.

17 Saifuddin, Pengelolaan, 111. 
yaitu system dan bahasa Yunani systema yang tersusun dari dua kata yaitu syn yang artinya dengan dan istanai berarti menempatkan." 18

Kata sistem juga dapat digunakan dalam ranah pendidikan, misalnya ialah sistem pendidikan nasional yaitu keseluruhan komponen yang berpadu dalam meraih tujuan yang diinginkan. Berdasarkan dari asal kata diatas dapat disimpulkan bahwa sistem adalah kumpulan dari beberapa hal yang digabungkan pada satu kesatuan yang saling berhubungan atau keterkaitan. Dengan adanya sistem pendidikan akan membentuk pencapaian keberhasilan belajar, namun juga harus ada kinerja yang saling mendukung sesama komponen dari pembelajaran.

a. Faktor yang Mempengaruhi Sistem Pembelajaran PAI

1) Murid atau Peserta Didik

Masing-masing peserta didik memiliki kemampuan yang berbedabeda. Misalnya kemampuan berpikir dan berperilaku, latar belakang dan karakter yang berbeda-beda.

2) Guru atau Pendidik

Secara umum peran guru adalah sebagai pendidik bagi peserta didik, fungsinya adalah untuk menyebarkan informasi dan pengetahuan. ${ }^{19}$ Demi mewujudkan tujuan pendidikan, seorang seorang guru berperan penting di dalamnya, seperti sebagai penggajar, pendidik, dan sebagainya. ${ }^{20}$

3) Tujuan Pembelajaran yang Hendak Dicapai

Menurut Darmadi menyampaikan bahwa "pada setiap pelaksanaan pembelajaran tentu ada tujuan dari pembelajaran yang dicapai."21 Adanya proses pembelajaran bertujuan supaya peserta didik dapat mendapatkan pengalaman belajar dan dapat memperbaiki perilaku peserta didik.

4) Faktor Materi Pembelajaran

Menurut Andi Prastowo mengungkapkan bahwa "materi pelajaran adalah materi yang digunakan untuk mencapai tujuan dari

\footnotetext{
18 Rifqi Amin, Sistem Pembelajaran Pendidikan Agama Islam Pada Perguruan Tinggi Umum (Yogyakarta: CV. Budi Utama, 2012), 33.

19 Darmadi, Guru Jembatan Revolusi (Surakarta: CV Kekata Group, 2018), 90.

20 Hidayatul Jannah dan Muhamad Ramli, "Kinerja Guru Pendidikan Agama Islam Dalam Pembelajaran Pada SMAN 1 Pelaihari," Al-Falah 17, no. 31 (Maret 2017): 59.

${ }^{21}$ Darmadi, Pengembangan, 178.
} 


\section{AL-ADABIYAH: Jurnal Pendidikan Agama Islam}

pembelajaran."22 Pada setiap materi pembelajaran memiliki tingkat kedalaman dan kerumitan yang berbeda. Artinya, materi pembelajaran tatarannya ada yang dangkal, sedang maupun sulit. Untuk itu, pemilihan metode pembelajaran secara efektif mampu mengatasi kesulitan suatu materi pembelajaran.

5) Situasi Belajar Mengajar

Pada setiap proses pembelajaran, memiliki situasi yang berbedabeda. Dan setiap peserta didik memiliki karakteristik yang tidak sama, untuk itu pendidik harusnya mengenal karakteristik pada setiap peserta didik beserta teori-teori belajar. Jadi, karakteristik peserta didik dan situasi pada saat pembelajaran dapat mempengaruhi sistem pembelajaran.

6) Fasilitas Belajar Mengajar

Pembelajaran akan mudah disampaikan dan diterima oleh peserta didik salah satunya melalui adanya fasilitas saat mengajar. Fasilitas adalah alat untuk memudahkan proses pembelajaran. Tidak semua sekolah memiliki fasilitas yang standar yang diinginkan, akan tetapi hal tersebut tidak menjadi halangan bagi pendidik untuk merancang pembelajaran. Pendidik yang berkompeten mampu menyelenggarakan pembelajaran yang menyenangkan, menarik dan dapat tercapai tujuan pembelajaran.

7) Faktor Alokasi Waktu Pembelajaran

Ketersediaan waktu dapat mempengaruhi metode pembelajaran, dimana dalam kegiatan pembelajaran ada pembukaan, inti dan penutup yang disusun secara sistematis. Untuk itu, pendidik harus menyesuaikan metode pembelajaran dengan alokasi waktu yang telah ditentukan supaya dapat mencapai tujuan yang sudah direncanakan.

2. Mata Pelajaran PAI

Adapun beragam pelajaran PAI yang diragamkan dalam beberapa mata pelajaran. Dalam hal ini proses pembelajaran PAI lebih dikomplekskan artinya dalam aplikasinya lebih diperdalam materinya. Adapun mata pelajaran PAI yang dipecah menjadi beberapa mata pelajaran seperti Fiqih, Akidah Akhlaq, Al-Quran Hadist, SKI (Sejarah Kebudayaan Islam). Proses pelaksanaan

${ }^{22}$ Andi Prastowo, Menyusun Rencana Pelaksanaan Pembelajaran (Jakarta: Kencana, 2017), 1. 


\section{AL-ADABIYAH: Jurnal Pendidikan Agama Islam}

dari masing-masing mata pelajaran yang mencakup PAI juga harus memperhatikan metode pembelajaran sesuai dengan kriteria mata pelajaran tersebut. Supaya pada setiap mata pelajaran tersebut dapat tercapai pemahaman dan tujuan yang sudah ditentukan.

\section{Metode}

Dalam penelitian ini penulis menggunakan pendekatan kualitatif, yang bersifat deskriptif. Deskriptif kualitatif mempelajari masalah-masalah yang ada serta tata cara kerja yang berlaku Penelitian deskriptif ini bertujuan untuk mendeskripsikan realitas yang ada di lapangan. Dengan kata lain penelitian deskriptif ini bertujuan untuk memperoleh informasi-informasi mengenai keadaan yang ada. Sedangkan untuk jenis pendekatan, peneliti menggunakan jenis pendekatan studikasus.

Dalam pengumpulan data, peneliti menggunakan teknik pengumpulan data sebagai berikut:

1. Observasi partisipatif moderat.

Observasi dilakukan dalam keadaan yang khusus disengaja ataupun tidak disengaja, baik secara langsung maupun tidak langsung terhadap subyek atau obyek yang diamati. ${ }^{23}$ Peneliti berusaha mengumpulkan data yakni ikut observasi partisipatif dalam beberapa kegiatan namun tidak keseluruhan. ${ }^{24}$

2. Wawancara semi struktur

Teknik pengambilan data yang dilakukan dalam penelitian ini adalah metode wawancara secara semi terstruktur. Peneliti ingin mengetahui secara pasti tentang informasi yang diperoleh berdasarkan pertanyaan yang tertulis.

3. Studu dokumentasi

Dalam teknik ini peneliti meminta data dari pihak sekolah, misalnya seperti meminta data yang berkaitan dengan fokus penelitian sebagai pendukung dalam hasil penelitian. Memotret maupun memvideo aktivitas yang ada relevansinya dengan penelitian.

Untuk analisis data, peneliti menggunakan teori menurut Matthew B. Miles, A.M. Huberman, dan J. Saldana yang dikutip oleh Alfi Haris Wanto di dalam jurnalnya yakni sebagai berikut:

\footnotetext{
${ }^{23}$ John W. Creswel, Research Design (Yogyakarta: Pustaka Belajar, 2010), 267.

${ }^{24}$ Sugiyono, Metode Penelitian Kuantitatif, Kualitatif dan R\&D (Bandung: Alfabeta, 2017), 226.
} 


\section{AL-ADABIYAH: Jurnal Pendidikan Agama Islam}

1. Kondensasi Data (Data Condensation)

Kondensasi data merujuk pada proses pemilahan, memfokuskan, menyederhanakan, mengabstrasikan dan menstransformasikan data yang mendekati kesulurhan wawancara-dokumen-dokumen dan materi empiris.

2. Penyajian Data (Data Display)

Dalam melakukan analisis yang lebih mendalam, peneliti membutuhkan penyajian data tujuannya agar peneliti dapat memahami konteks penelitian. Penyajian data merupakan pengorganisasian, penyatuan informasi yang disimpulkan.

3. Verifikasi dan Penarikan Kesimpulan (Drawing \& Verifying Conclusion)

Pada tahap ini peneliti mengumpulkan data dengan mencari pemahaman yang tidak memiliki pola, dan mencatat rincian keteraturan dalam penjelasan serta alur sebab akibat.

Dari pemaparan di atas dapat diambil kesimpulan bahwa dalam penelitian kualitatif merupakan temuan tersebut masih bersifat kurang jelas. Dengan demikian peneliti berupaya menggunakan teori yang sudah teruji hasilnya.

\section{Hasil dan Diskusi}

\section{Implementasi Metode Joyfull Learning di SMP Alam BIS}

Makna secara terminologi, metode joyfull learning pada hakikatnya merupakan cara yang digunakan oleh pendidik untuk peserta didik supaya menerima dengan baik materi yang disampaikan sehingga menciptakan proses pembelajaran yang tanpa ada tekanan, ketegangan dan kebosanan serta tidak terbatas oleh ruang kelas saja. ${ }^{25}$ Di dalam pembelajaran yang menyenangkan terdapat daya tarik yang kuat antara pendidik dan peserta didik dalam keadaan atau suasana yang tidak ada paksaaan di dalamnya termasuk tempat mereka belajar.

Lingkungan belajar yang baik ialah lingkungan yang menimbulkan tantangan, dorongan bagi peserta didik untuk belajar tanpa paksaan. Proses pembelajaran yang menyenangkan akan menciptakan suasana senang, mengesankan dan minat peserta didik untuk aktif sehingga tujuan pembelajaran dapat tercapai dengan maksimal. Disamping itu pendidik harus ada usaha keras untuk mencapai kemaksimalan pembelajaran.

\footnotetext{
${ }^{25}$ Saifuddin, Pengelolaan, 111.
} 


\section{AL-ADABIYAH: Jurnal Pendidikan Agama Islam}

Dengan mendesain materi pembelajaran yang mengedepankan peserta didik untuk berlibat aktif, misalnya membuat game, team quiz, role playing dan sebagainya. Namun proses pembelajaran tersebut tidak hanya berbatas pada ruang kelas saja, akan tetapi juga di luar kelas. Sehingga peserta didik mampu untuk berfikir, bereksplorasi, kreatif, dan memiliki yang mandiri. Jadi dapat disimpulkan bahwa joyfull learning adalah metode pembelajaran dengan penuh kegembiraan, menarik, tanpa memberikan paksaan untuk belajar pada peserta didik dan mendorong untuk aktif, kreatif dan berpikir kritis.

Dari penjabaran metode joyfull learning di atas relevan dengan pelaksanaan pembelajaran yang menyenangkan di SMP Alam BIS dalam mengembangkan minat belajar peserta didik. Pelaksanaan pembelajaran yang menyenangkan di sekolah tersebut dikemas dengan kegiatan belajar yang gembira seperti tanpa memberikan paksaan, menerapkan permainan edukatif, diterapkan moving class atau perpindahan tempat belajar ketika berganti mata pelajaran, ada outbound, outdoor class, pelaksanaan program TOT (Training Of Trainer) bagi semua siswa, proses pembelajarannya diiringi suara sholawat atau murrotal melalui loud speaker, menerapkan hafalan semua materi pelajaran dengan metode super memory rumus.

Kegiatan pembelajaran tersebut dapat memicu keadaan yang menyenangkan sehingga dapat menumbuhkan kembangkan minat belajar khususnya pada pembelajaran PAI bagi peserta didik. Menyenangkan yang dimaksud ialah membuat perasaan senang, tanpa tekanan. Pemaparan tersebut diperkuat dengan pendapat di dalam bukunya Ratno Harsanto ${ }^{26}$.

Menyenangkan adalah menjadikan senang, membuat bersuka hati, membangkitkan rasa senang hati, memuaskan, menarik hati, merasa puas dan sebagainya. Proses pembelajaran akan terasa menyenangkan jika peserta didik dapat aktif di dalamnya. Hal ini selaras dengan teori konsep belajar PAKEM kependekan dari pembelajaran yang partisipastif, aktif, kreatif, efektif dan menyenangkan. Sehingga diharapkan proses pembelajaran tersebut dapat mengembangkan minat peserta didik untuk belajar mata pelajaran pendidikan Agama Islam

Menurut Slameto yang dikutip oleh Donni menyatakan bahwa "minat adalah adanya perasaan lebih suka dan keterikatan pada suatu hal atau aktivitas, tanpa

\footnotetext{
${ }^{26}$ Radno Harsanto, Pengelolaan Kelas yang Dinamis: Paradigma Baru Pembelajaran Menuju Kompetensi Siswa (Yogyakarta: Kanisius, 2017), 20.
} 


\section{AL-ADABIYAH: Jurnal Pendidikan Agama Islam}

ada yang menyuruh."27 Sedangkan menurut Djamarah yang dikutip oleh Donni dalam bukunya mengemukakan bahwa "minat merupakan kecenderungan yang menetap untuk memerhatikan dan mengenang beberapa aktivitas. Jadi dapat disimpulkan bahwa minat belajar merupakan suatu kecenderungan dan dorongan kuat untuk memperhatikan maupun mengikuti suatu aktivitas yang timbul dari keinginan dirinya sendiri." 28

Pemaparan diatas relevan dengan wujud penerapan metode joyfull learning pada pembelajaran PAI yang diterapkan di SMP Alam BIS sangat menyenangkan, dimana pembelajarannya persuasif yaitu dapat mengajak peserta didiknya untuk belajar tanpa harus dipaksa, aktiv dalam bertanya dan menjawab pertanyaan, proses belajarnya berlangsung dengan kreatif baik dari pendidiknya maupun peserta didik. Disamping itu pendidik mampu efektif dalam menentukan pembelajaran secara baik sampai menentukan tempat belajar dan yang pasti sangat menyenangkan.

\section{Faktor Pendukung Dan Penghambat Implementasi Metode Joyfull Learning di SMP Alam BIS}

Berdasarkan wawancara dengan kepala sekolah dan guru mata pelajaran PAI ditemukan faktor pendukung dan penghambat dalam penggunaan metode joyfull learning terutama pada pembelajaran PAI. Faktor pendukung dan penghambat dapat berasal dari luar atau dari dalam diri sendiri. Faktor pendukung dalam pelaksanaan metode menyenangkan di SMP Alam BIS yaitu motivasi yang didapat dari semangat dari para peserta didik untuk belajar. Motivasi tersebut merupakan motivasi yang berasal dari luar atau ekstrinsik.

Penyataan di atas sesuai relevan dengan teori dari buku Sardiman bahwa motivasi ekstrinsik disebut dorongan yang aktivitasnya bermula berdasarkan dari luar artinya tidak berkaitan dengan diri individu. Dorongan ini muncul akibat pengaruh dari luar, berupa ajakan, perintah ataupun adanya paksaan dari orang lain. Motivasi berasal dari kata dasar motif, yang diartikan sebagai usaha yang mendongkrak seseorang untuk berbuat sesuatu. Kata motif pada umumnya dikatakan sebagai penggerak untuk melakukan aktivitas tertentu demi menggapai tujuan yang diinginkan. Maka dari itu, motivasi diartikan sebagai kekuatan

\footnotetext{
${ }^{27}$ Priansa, Pengembangan, 37.

${ }^{28}$ Priansa, 38.
} 


\section{AL-ADABIYAH: Jurnal Pendidikan Agama Islam}

penggerak seseorang untuk menjadi aktif. Pada umumnya motif akan menjadi aktif bila terdesak oleh kebutuhan yang dirasakan. ${ }^{29}$

Sedangkan faktor penghambat pelaksanaan metode joyfull learning pada pembelajaran PAI adalah pada pendidik atau guru. Kesulitan di awal yang dirasakan miss putri selaku guru mata pelajaran PAI ketika menerapkan metode joyfull learning adalah kurang dalam menciptakan kreativitas, namun lambat laun pendidik dapat beradaptasi dan terlatih dalam penggunaan metode tersebut. sebagai fasilitator seorang pendidik harus bisa mengarahkan peserta didiknya untuk berfikir dan bertindak dalam proses pembelajaran, mampu menyampaikan infoormasi dengan baik.

Berdasarkan hasil dari data yang diperoleh, pernyataan di atas selaras dengan teori yang menyatakan bahwa peran guru adalah sebagai pendidik bagi peserta didik, fungsinya adalah untuk menyebarkan informasi dan pengetahuan. ${ }^{30}$ Setiap pendidik atau guru memiliki kompetensi yang tidak sama satu sama lain harus mampu menciptakan dan mengajarkan pembelajaran yang kreatif. Kompetensi pada pendidik diakui dari latar pendidikan yang ditempuh. Kurangnya penguasaan terhadap berbagai metode menjadi hambatan dalam menentukan metode pembelajaran.

Ditambah, bila belum memiliki pengalaman mengajar, namun ada juga yang tepat memilih akan tetapi labilnya kepribadian pendidik dapat menjadi kendala saat mengajar. Dengan demikian, pendidik harus menyesuaikan metode yang hendak diterapkan dengan kemampuan penguasaan pendidik.

\section{Kesimpulan}

1. Penerapan metode joyfull learning pada pembelajaran PAI di SMP Alam BIS, pelaksanannya sangat menyenangkan, tidak membuat peserta didik tegang dan kaku ketika pembelajaran. Metode joyfull learning ini bukan hanya sekedar cara mengajarnya saja yang asyik, namun juga semua yang terlibat dalam proses pembelajaran, termasuk tempat belajarnya mendukung kelancaran dalam penggunaan metode tersebut.

2. Faktor pendukung dan penghambat implementasi metode joyfull learning pada pembelajaran Pendidikan Agama Islam pada peserta didik di SMP Alam BIS. Faktor pendukungnya bersumber pada semangat dari peserta didik untuk

\footnotetext{
${ }^{29}$ Sardiman, Interaksi \& Motivasi Belajar Mengajar, (Jakarta: PT. Grafindo Persada, 2016), 73.

${ }^{30}$ Darmadi, Guru Jembatan Revolusi (Surakarta: CV Kekata Group, 2018), 90.
} 
belajar PAI. Sedangkan untuk faktor penghambatnya hanyalah pada sisi kurangnya kreativitas dari pendidik dalam menerapkan game dan hal tersebut bukanlah penghambat yang berarti dalam melaksanakan pembelajaran PAI dengan metode joyfull learning.

\section{Referensi}

Amin, Rifqi. (2012). Sistem Pembelajaran Pendidikan Agama Islam Pada Perguruan Tinggi Umum. Yogyakarta: CV. Budi Utama

Bungin, M. Burhan. (2015). Penelitian Kualitatif. Jakarta: PT. Adhitya Andrebina Agung

Chatib, Munif dan Irma Nurul Fatimah. (2015). Kelasnya Manusia: Memaksimalkan Fungsi Otak Belajar dengan Manajemen Display Kelas. Bandung: Kaifa

Darmadi. (2017). Pengembangan Model Metode Pembelajaran dalam Diinamika Belajar Siswa. Yogyakarta: CV Budi Utama . (2018). Guru Jembatan Revolusi. Surakarta: CV Kekata Group

Darmono, Ikhwan Sapto. (2019) "Peningkatan Kinerja Guru Dalam Pembelajaran PAIKEM Melalui Supervisi Akademik Berkelanjutan Bagi Guru Kelas Di SD Negeri Pucangan 03 Kec. Kartasura tahun Pelajaran 2016/2017," Konvergensi 6(29), 30.

Dewi, Putri kumala dan Nia Budiana. (2018). Media Pembelajaran Bahasa: Aplikasi Teori Belajar dan Strategi Pengoptimalan Belajar. Malang: UB Press

Hanafi, Halid, La Adu, Muzakkir. (2018). Profesionalisme Guru Dalam Pengelolaan Kegiatan Pembelajaran Di Sekolah. Sleman: CV. Budi Utama

Harsanto, Radno. (2017). Pengelolaan Kelas yang Dinamis: Paradigma Baru Pembelajaran Menuju Kompetensi Siswa. Yogyakarta: Kanisius

Hayati, Nur. "Mendikbud Singgung Minimnya Pendidikan Agama di Sekolah," Serambinews, 21 Oktober 2019, retrieved from https:aceh.tribunnews.com/2018/05/06/mendikbud-singgung-minimnyapendidikan-agama-di-sekolah.

Hidayatul Jannah dan Muhamad Ramli. (2017). "Kinerja Guru Pendidikan Agama Islam Dalam Pembelajaran Pada SMAN 1 Pelaihari," Al-Falah, 17(31), 59.

Ingsih, Kusni dkk. (2018). Pendidikan Karakter: Alat Peraga Edukatif Media Interaktif. Yogyakarta: CV. Budi Utama

John W. Creswel. (2010). Research Design (Yogyakarta: Pustaka Belajar

Mariyaningsih, Nining dan Mistina Hidayati. (2018). Bukan Kelas Biasa: Teori dan Praktik Berbagai Model dan Metode Pembelajaran. Surakarta: CV Kekata Group 


\section{AL-ADABIYAH: Jurnal Pendidikan Agama Islam}

Nurjaman, Agus. (t,t). Joyfull Learning Mencuatkan Kreativitas Siswa. Bandung: Guepedia

Prastowo, Andi. (2017). Menyusun Rencana Pelaksanaan Pembelajaran (Jakarta: Kencana

Rukajat, Ajat. (2012). Teknik Evaluasi Pembelajaran. Yogyakarta: CV. Budi Utama

Rusman. (2016). Model-Model Pembelajaran: Mengembangkan Profesionalisme Guru Bandung: PT Rajagrafindo Persada

Sardiman. (2016). Interaksi \& Motivasi Belajar Mengajar. Jakarta: PT. Grafindo Persada

Sekretariat Negara RI, Undang-undang No 20 Tahun 2003 tentang Sistem Pendidikan Nasional

Sugiyono, Metode Penelitian Kuantitatif, Kualitatif dan $R \& D$ (Bandung: Alfabeta, 2017), 226.

Ulfatin, Nurul. (2010) Metode Penelitian Kualitatif di Bidang Pendidikan: Teori dan Aplikasinya. Malang: Media Nusa Creative

Umar, Bukhari. (2016). Hadis Tarbawi: Pendidikan dalam Perspektif Hadis Jakarta: Amzah

Zainiyati, Husniyatus Salamah. (2017). Pengembangan Media Pembelajaran Berbasis ICT Konsep dan Aplikasi Pada Pembelajaran Pendidikan Agama Islam Jakarta: Kencana 